\title{
Induction and Proliferation of Callus in the Flower Stalk of Calanthe discolor Lindl. and its Antioxidant Properties
}

\author{
Dong-Myong Kim ${ }^{1 *}$, Ju-Yeong Jung ${ }^{1}$, Hyung-Kon Lee ${ }^{1}$, Yong-Seong Kwon ${ }^{1}, K_{w a n}-H o L^{2}{ }^{2}$, Jin-Hoon Jang ${ }^{2}$, In-Suk Han ${ }^{3}$ \\ ${ }^{1}$ Biotechnology Research Institute, KJM Bio Ltd., Seoul, Korea \\ ${ }^{2}$ Department of Chemical Engineering \& Biotechnology, College of Engineering, Korea Polytechnic University, Siheung-si, Gyeonggi-do, Korea \\ ${ }^{3}$ Department of Chemical Engineering, College of Engineering, The University of Utah, Salt Lake City, USA
}

*Corresponding author: Dong-Myong Kim, Biotechnology Research Institute, KJM Bio Ltd, 17 Saimdang-ro, Seocho-gu, Seoul 06649, Korea

Tel.: +82 24056167

Fax: +82 24056154

Email: hapyvirus@naver.com

Received July 28, 2021

Revised August 17, 2021

Accepted September 3, 2021

Published September 30, 2021

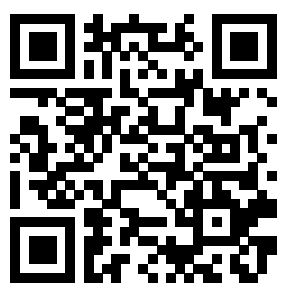

\begin{abstract}
Purpose: This study aims to establish the appropriate conditions for induction and proliferation of callus from the flower stalk of Calanthe discolor Lindl. (CFS) and to analyze the antioxidant properties as well as the skin irritation level of its extracts. Methods: Murashige \& Skoog medium was used to induce the callus from CFS with NBO ( $\alpha$-naphthaleneacetic acid (NAA) $0 \mathrm{mg} / \mathrm{L}$, benzyl adenine (BA) $0 \mathrm{mg} / \mathrm{L}$ ), NB1 (NAA $0.2 \mathrm{mg} / \mathrm{L}$, BA $0.1 \mathrm{mg} / \mathrm{L}$ ), NB5 (NAA $0.2 \mathrm{mg} / \mathrm{L}$, BA $0.5 \mathrm{mg} / \mathrm{L}$ ), and NB10 (0.2 mg/ $\mathrm{L}, \mathrm{BA} 1.0 \mathrm{mg} / \mathrm{L}$ ) as plant growth regulators (PGR). The callus powder was extracted by ultrasonic treatment, and the total phenolic contents (TPC), 2,2-diphenyl-1picrylhydrazyl (DPPH) radical scavenging activity, and human skin irritation test using callus extracts were performed. Results: As a result of callus induction from CFS with PGR, NB5 showed the highest growth rate of callus with a weight of $4.2 \pm 0.3 \mathrm{~g}$. The TPC of the callus extracts NBO, NB1, NB5, and NB10 were 33.71 $\pm 0.27,37.59 \pm 0.51$, $46.26 \pm 0.18$, and $55.92 \pm 0.33 \mathrm{mg} \mathrm{GAE} / \mathrm{g}$, respectively. NB10 showed the highest value of DPPH radical scavenging activity than that of NBO, NB1, NB5, and NB10, in various concentrations. CFS callus extract showed very low human skin irritation compared to that of the control group, 10\% SLS. Conclusion: The optimal PGR condition for induction of CFS callus was established as NB10. CFS callus extracts can be used as functional materials for cosmetics as it has significant antioxidant activity and low skin irritation value.
\end{abstract}

Keywords: Calanthe discolor, Flower stalk, Callus, Antioxidant activities, Skin irritation

\section{Introduction}

피부의 노화는 나이가 들어감에 따라 자연스럽게 발생하는 시간 의존적 내인성 노화와, 자외선 노출과 같은 주위 환경에 인한 광노 화(photoaging)로서 오랫동안 태양광에 노출된 얼굴, 손등, 목 뒤 등 의 피부에서 관찰되는 외인성 노화로 나눌 수 있다(Hwang et al., 2011; Seo, 2001). 이러한 노화는 여러가지 기작으로 설명될 수 있 는데, 그 중 하나는 산화적 스트레스(oxidative stress)에 지속적으로 노출되어 체내 자유라디칼(free radical)이 증가되는 것이다. 자외선 으로 생성된 활성산소 종(reactive oxygen species)은 실질적으로 피 부의 효소 및 비효소적 항산화 방어체계를 손상시키며 산화적 스트레 스는 피부의 염증반응 유발, 피부면역기능 억제, 세포성분의 손상을
야기시키고 광노화를 촉진한다(Garrel \& Fontecave, 1995; Hogg, 1995). 따라서 피부 세포를 보호할 수 있는 항산화 물질을 사용하여 피부 노화를 완화할 수 있는 소재 개발에 관한 연구가 많이 진행되고 있으며, 최근에는 엉겅퀴, 도라지, 계피 등의 천연물을 기능성 화장 품 소재로써 활용 가능성을 확인한 연구 논문이 다수 보고된 바 있다 (Park et al., 2019a; Park et al., 2019b; Lee \& Ryu, 2019). 이와 같이 기능성 화장품의 수요 증가 및 시장 규모 확대에 따라 천연물 성 분의 약리적 기능을 과학적으로 입증하고 이를 기능성 화장품으로 개 발하고자 하는 움직임이 활발히 진행되고 있다(Cho, 2011).

난초과(Orchidaceae)는 850 여개 이상의 속과 약 20,000 여개 종 을 가진 두 번째로 큰 화초과(flowering plant family)의 식물이다 (Gutiérrez, 2010). 난의 종류는 전 세계적으로 약 30만종 이상이 
알려져 있으며, 다양한 생리활성을 나타내는 유효성분들이 함유되 어 있음이 밝혀지고 있다. 지금까지 알려진 난초과 식물의 생리활 성으로는 항암, 항균, 항염, 항산화, 항당뇨, 항바이러스, 항알러지 활성을 포함하며 무수히 많은 활성을 가진 것으로 보고되었다. 특 히 난초과에 속하는 덴드로비움 종(Dendrobium spp.)의 항산화 효 과, 자란 종(Bletilla striata spp.)의 항산화, 미백 및 항암 효과, 천마 (Gastrodia elata spp.) 종의 신경보호 작용 등 많은 연구가 보고된 바 있다(Fan et al., 2009; Park et al., 2015; Sun et al., 2016; Zhao et al., 2007). 이러한 난초는 식물의 잎, 줄기, 뿌리 등 각각의 부위 별로 다양한 효능을 나타내는데, 최근에는 약용식물로써 난초의 이 용도를 높이고 종(species) 보존성을 높이기 위하여 다양한 식물 조 직 배양 방법이 시도되고 있다(Kayalvizhi et al., 2020; Pant, 2013; Pérez, 2010).

그 중에서도 새우난초속(Calanthe discolor Lindl.) 은 한국, 일본, 대만, 호주 등의 열대, 아열대 및 온대지역에 약 180 여종이 자생하고 있다. 국내 자생지는 제주도와 남부도서 일부 지역으로 알려져 있었 지만 지구온난화의 영향으로 중부 이북지역도 자생지로 보고되고 있 다(Hyun et al., 1999; Kim \& Kim, 1989). 새우난초는 난과 새우난 초속의 다년생 초본으로 잎이 지고 난 위 구경의 모양이 새우의 등처 럼 골이 지고 굽었다하여 새우난초라 명명되어졌다. 우리나라 새우 난초의 종류는 새우난초(Calanthe discolor Lindl.), 금새우난초 $(C$. discolor for. Sieboldii), 여름새우난초(C. reflexa Maxim) 등이 제주 도, 울릉도 등에 자생하고 있다(Hyun et al., 1999). 그러나 최근 새 우난초는 무분별한 채취로 인하여 자생지의 훼손이 심각하게 진행되 고 있다. 이에 따라 산림청 지정 멸종위기종으로 등재되어 보존 및 증식방법이 연구되고 있으며, 새우난초를 상업적으로 활용하기에는 희소성 및 경제성의 측면에서 불가능하다(Bae et al., 2010; Lee \& Kwack, 1983a; Lee \& Kwack, 1983b). 따라서 다양한 종의 난초과 식물이 약리 활성을 가지고 있어 민간요법에 사용되어 왔다고 보고된 것에 비해 새우난초를 이용한 생리활성물질에 관한 연구 결과는 미흡 한 실정이다(Kayalvizhi et al., 2020; Pant, 2013).

식물조직배양(plant tissue culture)은 식물의 세포 및 기관을 연중 균일하게 대량 생산하는 가장 보편적인 방법으로, 식물체로부터 기 관, 조직 및 세포를 적출 분리하여 기내에서 영양분이 함유되어 있는 배지를 이용해 무균 배양함으로써 캘러스(callus)를 단세포의 집단으 로 유기하거나 완전한 기능을 가진 식물체로 재생시키는 기술을 말한 다(Oh et al, 2014). 이때 캘러스는 식물체에서 잘라낸 조직을 식물 생장조절물질인 옥신(auxin)과 싸이토카인(cytokine)을 함유한 배지 에서 배양하거나, 식물체에 상처를 내거나 혹은 식물체의 절편을 옥 신으로 처리했을 때 발생된다. 최근에는 식물조직배양기술을 이용하 여 생리활성이 우수한 기능성 천연소재를 기능성 화장품 분야에 활 용하는 연구가 이루어지고 있는데, 이를 이용할 경우 특정 cell line 의 유지 및 보존, 주기적인 계대배양으로 인한 오염방지, 인건비 등 경비절감이 가능한 장점이 있다(Chenshu et al., 2003; Lee et al.,
2015).

최근에는 이러한 캘러스의 활용에 대해 관심이 고조되고 있고 4 차 산업혁명을 예고하는 스마트 팜(smart farm) 등의 최첨단 시설 에서 대량생산 목적으로 다양한 연구를 진행하고 있다. 현재 화장 품 분야에 있어서 식물의 캘러스 소재가 새로운 소재로 활용되고 있 으나 다양한 식물줄기세포 소재가 개발되지 못한 상황이며, 특히 새 우난초의 난꽃 줄기(Calanthe discolor Lindl's Flower Stalk, CFS) 로부터 유도된 캘러스의 생리활성에 관한 연구는 수행된 바 없었다 (Kayalvizhi et al, , 2020; Pant, 2013).

본 연구는 CFS 캘러스를 유도하기 위한 적정 조건을 확립하고, 이 러한 조건에서 생성된 CFS 캘러스 추출물의 생리활성 및 그 조성물 의 피부 자극도를 분석하고 항산화능이 있는 기능성 화장품으로의 이 용 가치를 확인하기 위한 목적으로 진행되었다.

\section{Methods}

\section{1. 실험 재료}

본 연구에서 사용된 새우난초의 난꽃 줄기(CFS)는 Biomed Herbal Research Biomedical Group (Taiwan)으로부터 공급받아 사용하였 다. CFS로부터 캘러스를 유도하기 위해 MS 기초배지(Murashige \& Skoog, 1962)를 사용하였으며, Duchefa Biochemie (Netherland) 에서 구입하였다. 그 외 실험에 이용된 모든 시약은 Sigma Aldrich (USA)에서 구입하였다.

\section{CFS 캘러스 유도, 추출 및 유효성분 분석}

1) CFS로부터 캘러스 유도

캘러스 유도용 배지는 다음과 같이 준비하였다. MS 기초배지 에 sucrose $40 \mathrm{~g} / \mathrm{L}$, hyponex $3.0 \mathrm{~g} / \mathrm{L}$, pepton $4.0 \mathrm{~g} / \mathrm{L}$, 바나나 파우더 $35.0 \mathrm{~g} / \mathrm{L}$, charcoal $2.0 \mathrm{~g} / \mathrm{L}$, agar $7.5 \mathrm{~g} / \mathrm{L}$ 를 첨가하였 다. 캘러스 유도에 영향을 주는 식물생장조절체로는 $0.1 \mathrm{mg} / \mathrm{L}$ 의 $\alpha$-naphthaleneacetic acid (NAA)와 $0,0.1,0.5,1.0 \mathrm{mg} / \mathrm{L}$ 의 4 가 지 농도로 나누어 benzyladenine (BA)을 첨가하였으며 $\mathrm{pH}$ 를 $5.75 \pm$ 0.05 으로 조정하였다. 무균처리한 $\mathrm{CFS}$ 를 최대한 작은 크기로 절취하 여 각각의 캘러스 유도용 배지에 치상하였다. 이때 기내배양 환경은 온도 $25 \pm 1^{\circ} \mathrm{C}$, 일장 $16 \mathrm{~h}$, 광도 $27 \mu \mathrm{mol} \cdot \mathrm{m}^{2} / \mathrm{s}$ 의 형광조명을 유지하 였다. 약 22-24주가 경과된 후, 배지에 치상된 CFS 절편에서 캘러스 가 유도되었다.

\section{2) CFS 캘러스 추출}

$\mathrm{CFS}$ 캘러스의 추출은 다음과 같이 실시하였다. 액화질소 상에서 분말화한 캘러스 분말 $70 \mathrm{~g}$ 에 4 배의 $70 \%$ 에탄올을 추출 용매로 가 하여 초음파세척기(Powersonic 405; Hwashin Tech, Korea)로 1 $\mathrm{h}$ 초음파 처리 후 실온에서 $24 \mathrm{~h}$ 추출하였다. 추출액은 필터페이퍼 
(WF2-1100; Whatman, UK)로 여과한 후 얻은 여액을 감압 농축하 여 에탄올 용매를 제거였다. 그 후 동결 건조하여 분말 형태의 CFS 캘러스 추출물을 얻었다. 추출물 분말은 $70 \%$ 에탄올에 $10 \mathrm{mg} / \mathrm{mL}$ 농도로 용해하여 이후 실험에 사용하였다.

\section{CFS 캘러스 추출물의 항산화도 분석}

1) 총 페놀 함량

CFS 캘러스 추출물의 총 페놀 함량은 Folin \& Denis (1912)의 방 법으로 분석하였다. 간단하게, $0.1 \% \mathrm{CFS}$ 캘러스 샘플 $50 \mu \mathrm{L}$, 증류수 $1.65 \mathrm{~mL}, 100 \mu \mathrm{L}$ Folin-Denis 시약을 혼합하고 $5 \mathrm{~min}$ 방치한 후 1 $\mathrm{N} \mathrm{Na}_{2} \mathrm{CO}_{3} 200 \mu \mathrm{L}$ 를 추가하여 실온에서 $2 \mathrm{~h}$ 반응시켰다. 그 후 분광 광도계(Spectronic Genesys 5; Milton Roy Company, USA)를 이용 하여 $750 \mathrm{~nm}$ 에서 흡광도를 측정하였다. 표준물질로 gallic acid를 사 용하여 시료의 총 페놀 함량을 산출하였으며, 그 값은 gallic acid 당 량값(mg GAE $/ \mathrm{g})$ 으로 나타내었다.

\section{2) $\mathrm{DPPH}$ 라디칼 소거활성}

CFS 캘러스 추출물의 2,2-diphenyl-1-picrylhydrazyl (DPPH) 라디칼 소거활성은 Blois (1958)의 방법을 살짝 변형하여 분석하였 다. 농도 $0.1,0.6,1.5 \mathrm{mg} / \mathrm{mL}$ 의 캘러스 추출물을 96 well plate 에 $10 \mu \mathrm{L}$ 씩 분주하고 $200 \mu \mathrm{M} \mathrm{DPPH}$ 용액을 $190 \mu \mathrm{L}$ 씩 가하여 혼합 한 후 $37^{\circ} \mathrm{C}$ 의 암실에서 $30 \mathrm{~min}$ 동안 반응시켰다. 그 후 분광광도계 (Biotrak II Plate reader; Amersham Life Science, UK)로 $550 \mathrm{~nm}$ 에서 흡광도를 측정하여 $\mathrm{DPPH}$ 라디칼 소거활성(\%)을 산출하였으며, 양성 대조군으로 quercetin을 사용하였다.

\section{4. 세포 독성 평가}

$\mathrm{CFS}$ 캘러스 추출물의 세포 독성 분석을 확인하기 위한 실험으 로 3-(4,5-dimethylthiazol-2-yl)-2,5-diphenyltetrazoli-um bromide (MTT) assay를 실시하였다(Kim et al., 2011). 마우스 대식 세포 RAW 264.7 cell $2 \times 10^{5}$ cells/well을 96 well plate에 $190 \mu \mathrm{L}$ 씩 분주하고 $37{ }^{\circ} \mathrm{C}$ 에서 $24 \mathrm{~h}$ 배양하였다. 그 후, 100 또는 $200 \mu \mathrm{g} / \mathrm{mL}$ 농도로 준비한 각각의 추출물 시료를 $100 \mu \mathrm{L}$ 씩 처리하고 $37{ }^{\circ} \mathrm{C}, 5 \%$ $\mathrm{CO}_{2}$ incubator에서 $24 \mathrm{~h}$ 배양하였다. 여기에 MTT 용액을 각 well마 다 $100 \mu \mathrm{L}$ 씩 첨가하여 $37^{\circ} \mathrm{C}$ 에서 $4 \mathrm{~h}$ 배양한 후, 배양액을 제거하고 DMSO:Ethanol (1:1) $100 \mu \mathrm{L}$ 를 가하고 실온에서 $30 \mathrm{~min}$ 반응시킨 뒤 분광광도계(Biotrak II Plate reader; Amersham Life Science,
$\mathrm{UK}$ )를 이용하여 $540 \mathrm{~nm}$ 에서 흡광도를 측정하였다.

\section{CFS 캘러스를 포함하는 조성물의 인체 피부 자극시험}

$\mathrm{CFS}$ 캘러스를 포함하는 조성물의 피부 자극도를 알아보기 위하여 헬싱키 선언에 근거한 윤리규정, 식품의약품안전처 인체적용시험가 이드라인의 관련 규정, 보건복지부의 생명윤리 및 안전에 관한 법률 에 따라 중앙대학교 피엔케이피부임상연구센타(P\&K Skin Research Center)에 의뢰하여 2017년 9월 23일자로 피부첩포시험을 실시하 였다(PNK-16905-M1R). 피험자 100명(평균연령 35세, 연령분포 만 20세-50세)을 대상으로 하여 각각 50명씩 10\% sodium lauryl sulfate (SLS) 적용 그룹과 $0.5 \%$ 캘러스 샘플 적용 그룹으로 나누 어 진행하였다. 이때 건선, 습진, 기타 피부병변 보유자나 임신, 수 유부 또는 피임제, 항히스타민제 등을 복용하고 있는 사람은 실험에 서 제외하였다. 시험부위인 상박 부위를 1 차 증류수로 닦아낸 후, 각 각의 그룹을 대상으로 정제수에 희석된 $10 \%$ SLS 및 $0.5 \%$ 캘러스 추 출물이 각 $20 \mu \mathrm{L}$ 씩 적용된 핀 챔버(Finn Chamber; SmartPractice, Denmark)를 상박 부위에 얹어 $3 \mathrm{M}$ Micropore Tape로 고정시켰다. 총 $24 \mathrm{~h}$ 동안 피부에 첩포(patch)를 적용하였으며, 첩포를 제거한 후 $1 \mathrm{~h}$ 후 시험물질 적용부위의 사진 촬영 및 시험자에 의한 피부반응 정도를 평가하였다. 또한, 챔버 제거 후 $24 \mathrm{~h}$ 째에 시험물질 적용부 위의 사진촬영 및 시험자에 의한 피부반응 정도를 평가하였다. 시험 자 육안평가는 Forsch \& Kligman과 The Cosmetic, Toiletry, and Frangrance Association (CTFA) guideline의 판정기준에 따라 자극 정도를 관찰하였다(Table 1). 피부 반응도와 자극지수는 아래의 식을 통해 산출하였다.

피부 반응도 $=\left(\left(\Sigma_{(i=1)}^{n_{1}}\right.\right.$ 평가값 $) /(n$ (시험대상자수 $\left.\left.)\right)\right)_{1 n}+\left(\left(\Sigma_{(i=1)}^{n_{1}}\right.\right.$ 평가 값 $) /(\mathrm{n}$ (시험대상자수) $))_{24 \mathrm{~h}}$

피부자극지수=(피부 반응도)/(n (평가횟수))

\section{6. 통계처리}

각 시료 간의 차이를 비교하기 위해 통계처리를 실시하였다. 모 든 시료에 대해서는 3 회 반복 실험을 진행하였으며 각 자료는 평균값 과 표준오차로 나타내었다. 통계분석은 SPSS (IBM SPSS Statistics, $\mathrm{NY}, \mathrm{USA}$ )를 사용하였고 $95 \%$ 유의수준에서 던컨(Duncan)의 일원배 치 다중시험 검정으로 각 처리 간의 유의적인 차이를 확인하였다.

Table 1. Recording of patch test reactions

\begin{tabular}{lcl}
\hline Indication & Grade & Indication standard \\
+ & 1 & Slight erythema, either spotty or diffuse \\
++ & 2 & Moderate uniform erythema \\
+++ & 3 & Intense erythema with edema \\
+++ & 4 & Intense erythema with edema and vesicles \\
\hline
\end{tabular}




\section{Results and Discussion}

\section{1. 식물생장조절체 농도에 따른 CFS 캘러스 유도 결과}

동일한 $\mathrm{MS}$ 기본배지에 식물생장조절체인 $\mathrm{NAA}$ 와 $\mathrm{BA}$ 의 첨가 농도 를 달리한 후 CFS 캘러스의 질량을 측정한 결과는 Table 2 에 나타내 었다. 각 샘플은 $\mathrm{NAA}$ 및 $\mathrm{BA}$ 각각의 농도에 따라 $\mathrm{NB} 0(\mathrm{NAA} 0, \mathrm{BA}$ 0), NB1 (NAA $0.2 \mathrm{mg} / \mathrm{L}, \mathrm{BA} 0.1 \mathrm{mg} / \mathrm{L}$ ), NB5 (NAA $0.2 \mathrm{mg} / \mathrm{L}$, $\mathrm{BA} 0.5 \mathrm{mg} / \mathrm{L})$ 및 NB10 $(0.2 \mathrm{mg} / \mathrm{L}, \mathrm{BA} 1.0 \mathrm{mg} / \mathrm{L})$ 로 명명하였다. 각각의 배지에서 유도된 캘러스의 질량을 분석한 결과, NB0, NB1, $\mathrm{NB} 5$ 및 NB10에서 각각 $1.1 \pm 0.0,2.3 \pm 0.3,3.5 \pm 0.3$ 및 4.2 \pm 0.3 $\mathrm{g}$ 의 질량을 가졌다. 이를 통해 $\mathrm{CFS}$ 캘러스는 식물생장조절체로 $\mathrm{BA}$ 가 첨가될수록 높은 성장률을 보이는 것이 확인되었다. 새우난초의 잎, 구경, 뿌리의 부정근을 유도한 연구에 따르면 $3.0 \mathrm{mg} / \mathrm{L}$ 의 BA와 $1.0 \mathrm{mg} / \mathrm{L}$ 의 NAA가 혼합된 배지에서 가장 높은 유도율을 갖는 것으 로 확인되었다. 첨가된 생장조절물질의 농도는 다르나 $\mathrm{BA}$ 의 농도가 높은 조건에서 높은 성장률을 보이는 양상이 동일하였다(Bae et al., 2010). 이를 통해서 캘러스의 분화 및 생장에는 세포의 생장과 분열 을 촉진하는 생장조절물질인 옥신과 사이토키닌의 첨가가 필수적이 며, 배지에 첨가하는 생장조절물질의 종류와 농도에 따라 분화 양상 이 다르게 나타남을 알 수 있었다(Murashige \& Skoog, 1962; Ryu et al., 1992).

\section{CFS 캘러스 추출물의 항산화도 분석 결과}

\section{1) 총 페놀 함량}

CFS 캘러스 추출물의 총 페놀 함량을 분석하여 gallic acid 당량값 으로 표시한 결과는 Figure 1에 나타내었다. 분석 결과, 시료 NBO, $\mathrm{NB} 1, \mathrm{NB} 5$ 및 NB10의 총 페놀 함량은 각각 $33.71 \pm 0.27,37.59 \pm$ $0.51,46.26 \pm 0.18$ 및 $55.92 \pm 0.33 \mathrm{mg} \mathrm{GAE} / \mathrm{g}$ 이었다. 이를 통해 $\mathrm{CFS}$ 는 캘러스 유도용 배지에 식물생장조절체인 NAA와 BA를 함께 첨가할수록, 이중에서도 $\mathrm{BA}$ 의 첨가량이 높을수록 유의적으로 높은 페놀 함량을 가진 캘러스가 유도되는 것을 확인하였다.

페놀성 화합물은 약리 식물, 채소 및 과일 등에서 주로 발견되는 성분으로 다양한 생리활성을 가진다고 알려져 있다. 폴리페놀에는

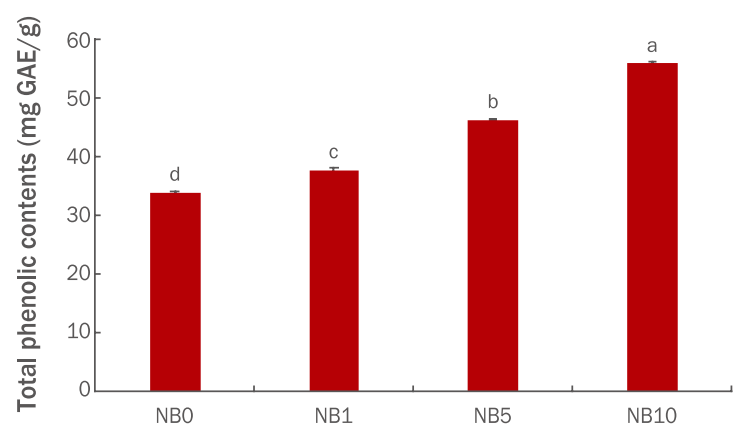

Figure 1. Total phenolic contents of Calanthe discolor flower stalk (CFS) callus extract.

NBO means the CFS callus induced with $\alpha$-naphthaleneacetic acid (NAA) $0 \mathrm{mg} / \mathrm{L}$ and benzyladenine (BA) $0 \mathrm{mg} / \mathrm{L}$; NB1 means the CFS callus induced with NAA $0.2 \mathrm{mg} / \mathrm{L}$ and BA $0.1 \mathrm{mg} / \mathrm{L}$; NB5 means the CFS callus induced with NAA $0.2 \mathrm{mg} / \mathrm{L}$ and BA $0.5 \mathrm{mg} / \mathrm{L}$; NB10 means the CFS callus induced with NAA 0.2 $\mathrm{mg} / \mathrm{L}$ and BA $1.0 \mathrm{mg} / \mathrm{L}$. Data represent the mean $\pm S$.D. with three separate experiments. Values with different alphabetical letters are significantly different at $p<0.05$ (ANOVA with post-hoc by Duncan test).

페놀산과 같은 생리활성에 작용하는 단일 분자부터 탄닌과 같은 고 분자화된 화합물들이 포함된다. 이들은 한 개 이상의 당 잔기들이 hydroxyl기와 결합하여 배당체 형태로 존재하고, 항산화, 항암, 혈 관확장, 항염증 등의 작용을 함으로써 많은 의학적 관심을 받고 있다 (Kähkönen et al., 1999). 난초과에 속하는 덴드로비움 종의 꽃 부 위의 에탄올추출물의 총 페놀 함량을 분석한 결과 $1.15-5.34 \mathrm{mg}$ $\mathrm{GAE} / \mathrm{g}$ 로, 새우난초 캘러스 추출물이 월등히 높은 값을 가지는 것이 확인되었다(Athipornchai \& Jullapo, 2018). 또한, 네팔 지역에 자생 하는 난초 식물에 관한 연구(Chand et al., 2016)에서 총 9 종의 난초 의 잎, 뿌리, 전초 부위의 에탄올 추출물의 총 페놀 함량을 분석한 결 과, $11.89-69.68 \mathrm{mg} \mathrm{GAE} / \mathrm{g}$ 가량의 값을 가졌으며, 평균적으로는 $37.59 \mathrm{mg} \mathrm{GAE} / \mathrm{g}$ 으로 본 실험의 새우난초 캘러스 추출물의 총 페놀 함량보다 적은 값을 가졌다. 새우난초 캘러스 추출물은 비교적 고함

Table 2. Effect of $\alpha$-naphthaleneacetic acid (NAA) and benzyladenine (BA) concentrations on callus formation of in vitro flower stalk of Calanthe discolor Lindl.

\begin{tabular}{llll}
\hline \multirow{2}{*}{ Sample } & \multicolumn{2}{c}{ Plant growth hormone $(\mathrm{mg} / \mathrm{L})$} & Callus weight $(\mathrm{g})$ \\
\cline { 2 - 3 } & $\mathrm{NAA}^{1)}$ & $\mathrm{BA}^{2)}$ & $1.1 \pm 0.0 \mathrm{~d}^{3)}$ \\
NB0 & 0 & 0 & $2.3 \pm 0.3 \mathrm{c}$ \\
NB1 & 0.2 & 0.1 & $3.5 \pm 0.3 \mathrm{~b}$ \\
NB5 & 0.2 & 0.5 & $4.2 \pm 0.3 \mathrm{a}$ \\
NB10 & 0.2 & 1.0 & \\
\hline
\end{tabular}

${ }^{1)} \alpha$-naphthaleneacetic acid. ${ }^{2)}$ benzyladenine. ${ }^{3)}$ Data represent means \pm S.D. of three separate experiments. Values with different alphabetical letters are significantly different at $p<0.05$ (ANOVA with post hoc by Duncan test). 


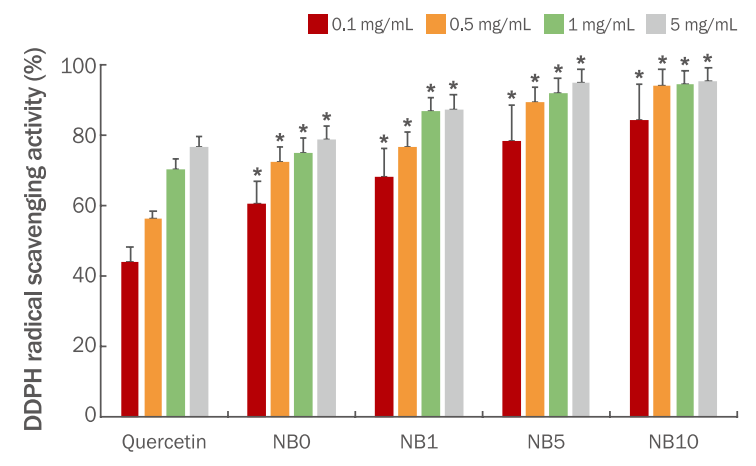

Figure 2. DPPH radical scavenging activity of Calanthe discolor flower stalk (CFS) callus extract depending on concentration. NBO means the CFS callus induced with $\alpha$-naphthaleneacetic acid (NAA) $0 \mathrm{mg} / \mathrm{L}$ and benzyladenine (BA) $0 \mathrm{mg} / \mathrm{L}$; NB1 means the CFS callus induced with NAA $0.2 \mathrm{mg} / \mathrm{L}$ and BA $0.1 \mathrm{mg} / \mathrm{L}$; NB5 means the CFS callus induced with NAA $0.2 \mathrm{mg} / \mathrm{L}$ and BA 0.5 $\mathrm{mg} / \mathrm{L}$; NB10 means the CFS callus induced with NAA $0.2 \mathrm{mg} / \mathrm{L}$ and BA $1.0 \mathrm{mg} / \mathrm{L}$. Differences between groups were statistically analyzed by ANOVA with post-hoc by Duncan test. " $p<0.05$ compared to same concentration of quercetin-treated group.

량으로 페놀성 화합물을 함유하고 있으며, 이를 통해 다양한 생리활 성을 가질 수 있음을 확인하였다. 다만, 다양한 난초 종의 캘러스에 관한 연구는 미흡한 실정으로 본 연구 결과와의 비교가 어렵기 때문 에 추후 후속 연구를 통한 비교가 필요할 것으로 사료된다.

\section{2) $\mathrm{DPPH}$ 라디칼 소거 활성}

유리 라디칼은 생물학적 손상의 주요 요인으로 잘 알려져 있는데, $\mathrm{DPPH}$ 는 천연 항산화제의 유리 라디칼 소거능을 평가하는데 일반적 으로 사용된다(Seo et al., 2006). CFS 캘러스 추출물의 천연 항산화 제로써 활성을 확인하기 위해 $\mathrm{DPPH}$ 라디칼 소거능 분석을 실시하였 으며, 그 결과는 Figure 2에 나타내었다. 양성 대조군인 quercetin을 비롯하여 CFS 캘러스 추출물 시료 NB0, NB1, NB5, NB10은 모두 농도 의존적으로 활성이 높은 모습을 보였으며, 캘러스 유도 시 첨 가된 식물생장조절체로 $\mathrm{BA}$ 의 농도가 높을수록 활성이 높았다. 농도 별로 결과를 살펴보면, $0.1 \mathrm{mg} / \mathrm{mL}$ 에서 $\mathrm{DPPH}$ 라디칼 소거 활성은 quercetin이 44.01\%, NB0, NB1, NB5, NB10에서 60.46-84.16\% 이었으며, $0.5 \mathrm{mg} / \mathrm{mL}$ 에서는 quercetin $56.11 \%$, NB0, NB1, NB5, $\mathrm{NB} 10$ 에서 72.47-93.82\%으로 모든 처리군은 quercetin보다 높은 항산화 활성을 보였다. 마찬가지로, 농도 $1 \mathrm{mg} / \mathrm{mL}$ 및 $5 \mathrm{mg} / \mathrm{mL}$ 에 서 quercetin의 DPPH 라디칼 소거활성이 각각 $70.23 \%, 76.42 \%$ 였 으나, $\mathrm{NB} 0, \mathrm{NB} 1, \mathrm{NB} 5, \mathrm{NB} 10$ 에서 각각 74.94-94.35\% 및 78.58$95.33 \%$ 범위로 대조군에 비해 더 높은 활성을 가지는 것이 확인되었 다. 특히 CFS 캘러스 유도 시 식물생장조절체로 $0.2 \mathrm{mg} / \mathrm{L}$ 의 NAA 및 $1.0 \mathrm{mg} / \mathrm{L}$ 의 $\mathrm{BA}$ 가 첨가된 처리군 $(\mathrm{NB} 10)$ 에서 가장 활성이 높은 것으로 나타났다.

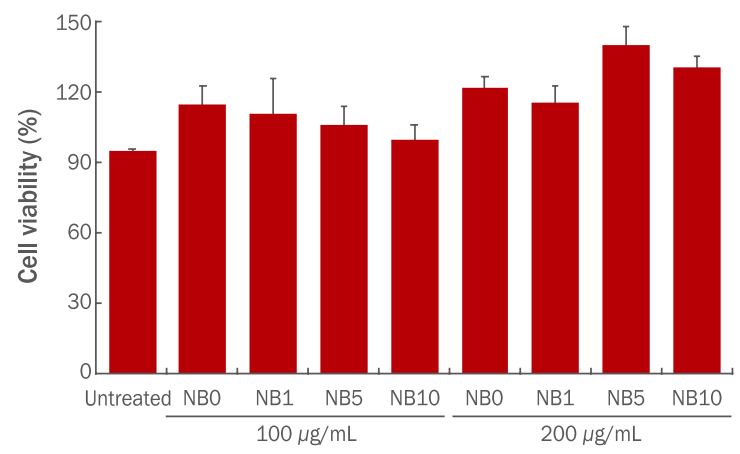

Figure 3. Effect of Calanthe discolor flower stalk (CFS) callus extracts on the cell viability of RAW 264.7 cells.

Untreated means the group treated nothing; NBO means the CFS callus induced with $\alpha$-naphthaleneacetic acid (NAA) $0 \mathrm{mg} / \mathrm{L}$ and benzyladenine (BA) $0 \mathrm{mg} / \mathrm{L}$; NB1 means the CFS callus induced with NAA $0.2 \mathrm{mg} / \mathrm{L}$ and BA $0.1 \mathrm{mg} / \mathrm{L}$; NB5 means the CFS callus induced with NAA $0.2 \mathrm{mg} / \mathrm{L}$ and BA $0.5 \mathrm{mg} / \mathrm{L}$; NB10 means the CFS callus induced with NAA $0.2 \mathrm{mg} / \mathrm{L}$ and BA $1.0 \mathrm{mg} / \mathrm{L}$. Data represent the mean \pm S.D. with three separate experiments.

생체 내에서 발생하는 hydroxyl radical $(\cdot \mathrm{OH})$, super oxide radical $\left(\mathrm{O}_{2}{ }^{-}\right)$, hydroperoxyl radical $\left(\mathrm{HO}_{2}^{-}\right)$, singlet oxygen $\left({ }^{1} \mathrm{O}_{2}\right)$, hydrogen peroxide $\left(\mathrm{H}_{2} \mathrm{O}_{2}\right)$ 등과 같은 활성산소종에 의한 산화적 대 사의 부산물은 노화의 원인으로 손꼽히고 있으며(Wiseman, 1996), 이러한 활성산소종을 조절하는데 관여하는 물질로 여러 항산화제가 존재한다(Choi et al., 2003; Kim \& Kim, 2006; Lee et al., 2004). 최근에는 식품과 화장품에 다양한 소재들이 천연 항산화제로 활용 되고 있으며 관련된 연구도 활발하게 이루어지고 있다. 본 연구에서 $\mathrm{CFS}$ 캘러스 추출물의 DPPH 라디칼 소거능을 분석한 결과 대조군인 quercetin보다 높은 항산화도를 가져 천연 항산화제로 사용될 수 있 음이 확인되었다. 또한, 앞선 총 페놀 함량 분석 결과와 비교해 보았 을 때, $\mathrm{DPPH}$ 라디칼 소거능은 총 페놀 함량과 동일한 경향으로 증가 하였으며 이를 통해 항산화 활성과 페놀성 화합물 간의 상관관계를 확인할 수 있었다.

\section{3. 세포 독성 평가 결과}

마우스 대식세포인 RAW 264.7 세포에 대한 CFS 캘러스 추출물의 세포 독성을 알아보기 위해 MTT assay를 수행한 결과는 Figure 3에 나타내었다. CFS 캘러스 추출물 시료 NB0, NB1, NB5, NB10을 각 각 100 및 $200 \mu \mathrm{g} / \mathrm{mL}$ 로 $24 \mathrm{~h}$ 처리한 결과, $\mathrm{NB} 0, \mathrm{NB} 1, \mathrm{NB} 5, \mathrm{NB} 10$ 모두 세포 생존율이 95\% 이상으로 RAW 264.7 세포에 독성을 나타 내지 않았다.

\section{CFS 캘러스 추출물의 인체 피부 자극시험 결과}

CFS 캘러스 추출물에 대해 인체피부에서의 피부자극 정도를 평가 하기 위하여 인체 첩포시험을 실시하였다. 자극원으로 주로 사용되 
Table 3. Results of human skin primary irritation test of SLS and $C$. discolor flower stalk callus extract

\begin{tabular}{|c|c|c|c|c|c|c|}
\hline \multirow{2}{*}{ Sample } & \multirow{2}{*}{$\begin{array}{l}\text { Number } \\
\text { of subjects }\end{array}$} & \multicolumn{4}{|c|}{ Indication $^{1)}$} & \multirow{2}{*}{$\begin{array}{c}\text { Stimulus } \\
\text { degree }\end{array}$} \\
\hline & & ++++ & +++ & ++ & + & \\
\hline $10 \% \mathrm{SLS}^{2)}$ & 50 & 10 & 28 & 10 & 2 & 1.92 \\
\hline $0.5 \%$ CFS callus extract ${ }^{3)}$ & 50 & 0 & 0 & 1 & 49 & 0.02 \\
\hline
\end{tabular}

${ }^{1)}$ Indication standard: (+) Slight erythema, either spotty or diffuse; (++) Moderate uniform erythema; (+++) Intense erythema with edema; (++++) Intense erythema with edema and vesicles. ${ }^{2)}$ Sodium lauryl sulfate. ${ }^{3)} \mathrm{C}$. discolor flower stalk callus extract.

는 $10 \%$ SLS와 $0.5 \%$ 캘러스 추출물에 대해 각각 50 명씩 시험군을 나누어 첩포시험을 실시한 결과는 Table 3 에 나타내었다. $10 \%$ SLS 를 첩포 후 제거한 시험군의 경우, 붓기와 수포를 동반한 강한 홍반 (++++; grade 4)이 나타난 피험자가 10명, 붓기를 동반한 강한 홍 반(+++; grade 3)이 나타난 피험자가 28명, 일정한 홍반(++; grade 2)이 나타난 피험자가 10명, 그리고 가벼운 홍반(+; grade 1)이 나타 난 피험자가 1 명이었으며 피부자극지수는 1.92 로 매우 높은 자극성 을 보였다. 그에 반해 $0.5 \%$ 캘러스 추출물을 첩포 후 제거한 시험군 의 경우, grade 4 와 grade 3 에 해당하는 피험자는 모두 0 명 이었으 며, grade 2에 해당하는 피험자가 1명, 그리고 grade 1에 해당하는 피험자가 49 명이었다. 이 경우 피부자극지수는 0.02 로 새우난초 캘 러스 추출물은 매우 높은 확률로 홍반이나 특이현상을 발생시키지 않 으며 저자극성인 것으로 확인되었다. 이를 통해서 CFS 캘러스 추출 물은 기능성 화장품 원료로서 이용이 가능할 것으로 생각되었다.

\section{Conclusion}

새우난초의 난꽃 줄기(Calanthe discolor Lindl's Flower Stalk, $\mathrm{CFS)}$ 는 다양한 생리활성물질을 통한 약리활성을 보유하고 있으나, 수급의 불안정성으로 인해상업화가 쉽지 않은 실정이다. 이에 본 연 구는 CFS 캘러스를 유도하기 위한 적정 조건을 확립하고 이러한 조 건에서 생성된 CFS 캘러스 추출물의 생리활성 및 피부자극도를 분석 함으로써 기능성 화장품으로의 이용 가치를 확인하기 위한 목적으로 진행되었다.

$\mathrm{CFS}$ 캘러스를 유도하기 위한 식물생장조절체의 적정 농도를 확인 하기 위해 NBO (NAA 0, BA 0), NB1 (NAA $0.2 \mathrm{mg} / \mathrm{L}, \mathrm{BA} 0.1 \mathrm{mg} /$ L), NB5 (NAA $0.2 \mathrm{mg} / \mathrm{L}, \mathrm{BA} 0.5 \mathrm{mg} / \mathrm{L})$ 및 NB10 $(0.2 \mathrm{mg} / \mathrm{L}, \mathrm{BA}$ $1.0 \mathrm{mg} / \mathrm{L}$ )으로 나누어 캘러스를 유도한 결과, 샘플 $\mathrm{NB} 5$, 즉, $\mathrm{BA}$ 의 농도가 높아지는 조건에서 높은 캘러스 성장률을 보였으며, 본 조 건에서의 캘러스의 질량은 $4.2 \pm 0.3 \mathrm{~g}$ 이었다. CFS 캘러스 추출물 의 항산화도 분석 결과, $\mathrm{NB} 0, \mathrm{NB} 1, \mathrm{NB} 5$ 및 $\mathrm{NB} 10$ 의 총 페놀 함량 은 각각 $33.71 \pm 0.27,37.59 \pm 0.51,46.26 \pm 0.18$ 및 $55.92 \pm 0.33$ $\mathrm{mg} \mathrm{GAE} / \mathrm{g}$ 으로 식물생장조절체 $\mathrm{BA}$ 의 첨가량이 높을수록 유의적으 로 높은 페놀 함량을 가진 캘러스가 유도되었다. 또한, 추출물 농도별
$\mathrm{NB} 0, \mathrm{NB} 1, \mathrm{NB} 5, \mathrm{NB} 10$ 의 $\mathrm{DPPH}$ 라디칼 소거 활성 분석 결과, 캘러 스 유도 시 식물생장조절체로 $0.2 \mathrm{mg} / \mathrm{L}$ 의 NAA 및 $1.0 \mathrm{mg} / \mathrm{L}$ 의 BA 가 첨가된 처리군(NB10)에서 가장 활성이 높은 것으로 나타났다. 마 지막으로 CFS 캘러스 추출물의 자극성을 확인하기 위하여 인체 피부 첩포시험을 실시하였으며 대조군은 $10 \% \mathrm{SLS}$ 에 비하여 CFS 캘러스 추출물은 매우 낮은 자극성을 보였다.

본 연구를 통해서 CFS 캘러스의 유도 적정 조건을 확립하였으며, 항산화능이 있는 기능성 및 저자극성을 확인함으로써 화장품 원료로 써 이용 가치를 확인하였다는 점에서 큰 의의가 있다.

\section{Acknowledgements}

본 논문은 2018년도 중소벤처기업부의 재원(과제번호: $\mathrm{S} 2594138)$ 과 산업통상자원부의 재원(과제번호: N0001395)으로 기술개발 지원사업의 지원을 받아 수행된 연구임.

\section{Author's contribution}

HKL performed the preparation of the samples. JYJ, KHL and JHJ performed the preparation of the samples and efficacy test. ISH, and YSK assisted with experimental design and analyzed data. DMK designed this project and wrote the manuscript with assistance from JYJ.

\section{Author details}

Dong-Myong Kim (Chief Technical Officer), Biotechnology Research Institute, KJM Bio Ltd, 17 Saimdang-ro, Seocho-gu, Seoul 06649, Korea; Ju-Yeong Jung (Senior Researcher), Biotechnology Research Institute, KJM Bio Ltd, 17 Saimdang-ro, Seocho-gu, Seoul 06649, Korea; Hyung-Kon Lee (Senior Researcher), Biotechnology Research Institute, KJM Bio Ltd, 17, Saimdang-ro, Seocho-gu, Seoul 06649, Korea; Yong-Seong Kwon (Research Director), Biotechnology Research Institute, KJM Bio Ltd, 17, Saimdang-ro, Seocho-gu, Seoul 06649, Korea; Kwan-Ho Lee (Research Student), Department of Chemical Engineering \& Biotechnology, College of Engineering, 
Korea Polytechnic University, 237 Sangidaehak-ro, Siheung-si, Gyeonggi-do 15073, Korea; Jin-Hoon Jang (Research Student), Department of Chemical Engineering \& Biotechnology, College of Engineering, Korea Polytechnic University, 237 Sangidaehak-ro, Siheung-si, Gyeonggido 15073, Korea; In-Suk Han (Professor), Department of Chemical Engineering, College of Engineering, The University of Utah, Salt Lake City, UT84112, USA.

\section{References}

Athipornchai A, Jullapo N. Tyrosinase inhibitory and antioxidant activities of Orchid (Dendrobium spp.). South African Journal of Botany, 119: 188-192, 2018.

Bae KH, Yoon ES, Yun PY, Choi YE. Soil acclimatization of Calanthe discolor through multiple shoot formation from tissue culture. Korean Journal of Plant Resources, 23: 7-13, 2010.

Blois MS. Antioxidant determinations by the use of a stable free radical. Nature, 181: 1199-1200, 1958.

Chand MB, Paudel MR, Pant B. The antioxidant activity of selected wild orchids of Nepal. Journal of Coastal Life Medicine, 4: 731-736, 2016.

Chenshu A, Wang X, Yuan X, Zhao B, Wang Y. Optimization of cryopreservation of Artemisia annua L. callus. Biotechnology Letters, 25: 35-38, 2003.

Cho YJ. Characteristics of cosmetic with whitening compounds from Phellodendron amurense. Journal of Applied Biological Chemistry, 54: 108-113, 2011.

Choi JS, Oh JI, Hwang IT, Kim SE, Chun JC, Lee BH, Kim JS, Kim TJ, Cho KY. Application and high throughput screening of DPPH free radical scavenging activity by using 96-well plate. The Korean Journal of Pesticide Science, 7: 92-99, 2003.

Fan Y, He X, Zhou S, Luo A, He T, Chun Z. Composition analysis and antioxidant activity of polysaccharide from Dendrobium denneanum. International Journal of Biological Macromolecules, 45: 169-173, 2009.

Folin O, Denis W. On phosphotungstic-phosphomolybdic compounds as color reagents. Journal of Biological Chemistry, 12: 239-243, 1912.

Garrel C, Fontecave M. Nitric oxide: chemistry and biology. In Analysis of free radicals in biological systems. Favier A,
Cadet J, Kalyanaraman B, Fontecave M, Pierre JL(Eds.). Birkhäuser Basel, Switzerland, pp21-35, 1995.

Gutiérrez RMP. Orchids: a review of uses in traditional medicine, its phytochemistry and pharmacology. Journal of Medicinal Plants Research, 4: 592-638, 2010.

Hogg N. Pro-oxidant and antioxidant effects of nitric oxide. Analysis of free radicals in biological systems. Favier A, Cadet J, Kalyanaraman B, Fontecave M, Pierre JL(Eds.). Birkhäuser Basel, Switzerland, pp37-49, 1995.

Hwang JG, Yun JK, Han KH, Do EJ, Lee JS, Lee EJ, Kim JB, Kim MR. Anti-oxidation and anti-aging effect of mixed extract from Korean medicinal herbs. The Korea Journal of Herbology, 26: 111-117, 2011.

Hyun MR, Choi JY, Suh JN, So IS, Lee JS. Studies on distributions and morphological characteristics of Calanthe discolor, C. sieboldii, and $C$. bicolor native to Cheju Province. Horticultural Science \& Technology, 17: 497-499, 1999.

Kähkönen MP, Hopia Al, Vuorela HJ, Rauha J-P, Pihlaja K, Kujala TS, Heinonen M. Antioxidant activity of plant extracts containing phenolic compounds. Journal of Agricultural and Food Chemistry, 47: 3954-3962, 1999.

Kayalvizhi K, Divya K, Sankari A. Medicinal Orchids-an overview. Biotica Research Today, 2: 1084-1087, 2020.

Kim DH, An BJ, Kim SG, Park TS, Park GH, Son JH. Antiinflammatory effect of Ligularia fischeri, Solidago virgaaurea and Aruncus dioicus complex extracts in Raw 264.7 cells. Journal of Life Science, 21: 678-683, 2011.

Kim SJ, Kim GH. Quantification of quercetin in different parts of onion and its DPPH radical scavenging and antibacterial activity. Food Science and Biotechnology, 15: 39-43, 2006.

Kim YS, Kim SH. A taxonomic study on Calanthe in Korea. Korean Journal of Plant Taxonomy, 19: 273-287, 1989.

Lee JS, Kwack BH. Classification of horticultural cultivars on cultivated Calanthe discolor Lindle native to Korea. Horticulture, Environment, and Biotechnology, 24: 144148, 1983a.

Lee JS, Kwack BH. Classification of horticultural cultivars on cultivated Calanthe striata R. Br. in Korea. Horticulture, Environment, and Biotechnology, 24: 62-67, 1983b.

Lee KM, Jeong GT, Park DH. Study of antimicrobial and DPPH radical scavenger activity of wood vinegar. Korean Society for Biotechnology and Bioengineering Journal, 19: 381- 
384, 2004.

Lee NN, Choi YE, Moon HK. Somatic embryo induction and plant regeneration from cold-stored embryogenic callus of K. septemlobus. Journal of Plant Biotechnology, 42: 388395, 2015.

Lee YS, Ryu MJ. Antioxidant effects of Cinnamomum cassia bark extract and its effectiveness as a cosmetics ingredient. Asian Journal of Beauty and Cosmetology, 17: 69-80, 2019.

Murashige T, Skoog F. A revised medium for rapid growth and bio assays with tobacco tissue cultures. Physiologia plantarum, 15: 473-497, 1962.

Oh ST, Jung HS, Cho MJ, Song MY, Moh SH, Seo HH. Effect of Artemisia annua Linne callus induced by plant cell culture technology on wound healing. The Korea AcademiaIndustrial cooperation Society, 15: 5628-5636, 2014.

Pant B. Medicinal orchids and their uses: tissue culture a potential alternative for conservation. African Journal of Plant Science, 7: 448-467, 2013.

Park JP, Lee SI, Jeong JK. A study on functional components, antioxidant activity of Gastrodiae rhizoma and Gastrodiae elata floral axis. The Korea Journal of Herbology, 30: 1924, 2015.

Park JY, Lee JY, Lee DY, Kim HD, Kim GS, Lee SE, Seo KH. Melanogenesis inhibitory effect of steamed Platycodon grandiflorum on B16F10 Cells. Asian Journal of Beauty and Cosmetology, 17: 37-46, 2019a.

Park YE, Kwon GS, Kim BH, Lee JB. Evaluation of the usefulness of the fermented thistle (Cirsium japonicum) with Lactobacillus rhamnosus BHN-LAB105 for antioxidative and whitening effects. Asian Journal of Beauty and Cosmetology, 17: 1-3, $2019 \mathrm{~b}$.

Pérez G. Orchids: a review of uses in traditional medicine, its phytochemistry and pharmacology. Journal of Medicinal Plants Research, 4: 592-638, 2010.

Ryu JH, Doo HS, Kwon TH. Induction of haploid plants by anther culture in sesame (Sesamum indicum L.)-(1)-effects of growth regulators and difference between genotypes on callus induction. Korean Journal of Plant Tissue Culture, 19: 171-177, 1992.

Seo BY, Jung ES, Kim JY, Park HR, Lee SC, Park E. Effect of aceton extract from Styela clava on oxidative DNA damage and anticancer activity. Journal of Applied Biological Chemistry, 49: 227-232, 2006.

Seo JY. Skin aging from phenotype to mechanism. Korean Journal of Investigative Dermatology, 8: 187-194, 2001.

Sun A, Liu J, Pang S, Lin J, Xu R. Two novel phenanthraquinones with anti-cancer activity isolated from Bletilla striata. Bioorganic \& Medicinal Chemistry Letters, 26: 23752379, 2016.

Wiseman H. Dietary influences on membrane function: importance in protection against oxidative damage and disease. The Journal of Nutritional Biochemistry, 7: 2-15, 1996.

Zhao Y, Son YO, Kim SS, Jang YS, Lee JC. Antioxidant and antihyperglycemic activity of polysaccharide isolated from Dendrobium chrysotoxum Lindl. Journal of Biochemistry and Meolecular Biology, 40: 670-677, 2007. 


\section{국문초록}

\section{새우난초 줄기에서부터 캘러스 유도 및 이의 항산화 활성}

김동명 ${ }^{1 *}$, 정주영 ${ }^{1}$, 이형곤 ${ }^{1},{\text { 권용성 }{ }^{1} \text {, 이관호 }}^{2}$, 장진훈 ${ }^{2}$, 한인석 $^{3}$

${ }^{1}$ (주)케이제이엠바이오 바이오연구소, 서울, 한국

${ }^{2}$ 한국산업기술대학교 생명화학공학과, 시흥시, 한국

${ }^{3}$ 유타대학교 화학공학과, 솔트레이크, 미국

목적: 본 연구는 새우난초의 난꽃 줄기(Calanthe discolor Lindl's Flower Stalk, CFS)로부터 캘러스를 유도하기 위한 적정 조건을 확 립하고 이러한 조건에서 생성된 CFS 캘러스 추출물의 항산화도 및 피부자극도를 분석함으로써 항산화능이 있는 기능성 화장품으 로의 이용 가치를 확인하기 위해 진행되었다. 방법: CFS 캘러스를 유도하기 위해 Murashige \& Skoog 기초배지를 이용하였으며 이때 식물생장조절체의 적정 농도를 확인하기 위해 NB0 ( $\alpha$-naphthaleneacetic acid (NAA) 0, benzyladenine (BA) 0), NB1 (NAA $0.2 \mathrm{mg} / \mathrm{L}, \mathrm{BA} 0.1 \mathrm{mg} / \mathrm{L}), \mathrm{NB} 5$ (NAA $0.2 \mathrm{mg} / \mathrm{L}, \mathrm{BA} 0.5 \mathrm{mg} / \mathrm{L}$ ) 및 NB10 (0.2 mg/L, BA $1.0 \mathrm{mg} / \mathrm{L})$ 으로 나누어 배양하였다. 캘 러스 분말을 초음파 처리하여 추출하였으며, 추출물의 총 페놀함량, $\mathrm{DPPH}$ 항산화도 분석 및 인체 피부 자극시험을 진행하였다. 결 과: CFS 캘러스 샘플 NB5는 BA의 농도가 높아지는 조건에서 높은 캘러스 성장률을 보였으며, 본 조건에서의 캘러스의 질량은 4.2 $\pm 0.3 \mathrm{~g}$ 이었다. CFS 캘러스 추출물의 항산화도 분석 결과, NB0, NB1, NB5 및 NB10의 총 페놀 함량은 각각 $33.71 \pm 0.27,37.59$ $\pm 0.51,46.26 \pm 0.18$ 및 $55.92 \pm 0.33 \mathrm{mg} \mathrm{GAE} / \mathrm{g}$ 으로 식물생장조절체 $\mathrm{BA}$ 의 첨가량이 높을수록 유의적으로 높은 페놀 함량을 가진 캘러스가 유도되었다. 또한, CFS 추출물 농도별 NB0, NB1, NB5, NB10의 2,2-diphenyl-1-picrylhydrazyl (DPPH) 라디칼 소거 활성 분석 결과, 캘러스 유도 시 식물생장조절체로 $0.2 \mathrm{mg} / \mathrm{L}$ 의 NAA 및 $1.0 \mathrm{mg} / \mathrm{L}$ 의 BA가 첨가된 처리군(NB10)에서 가장 활성이 높은 것으로 나타났다. 마지막으로 CFS 캘러스 추출물의 자극성을 확인하기 위하여 인체 피부 첩포시험을 실시하였으며 대조군은 $10 \% \mathrm{SLS}$ 에 비하여 CFS 캘러스 추출물은 매우 낮은 자극성을 보였다. 결론: CFS 캘러스의 유도 적정 조건을 확립하였으며, 항산화 활성 및 저자극성을 확인함으로써 항산화능이 있는 기능성 화장품 원료로써 이용 가치를 확인하였다.

핵심어: 새우난초, 난꽃 줄기, 캘러스, 항산화도, 피부 자극

본 논문은 2018년도 중소벤처기업부의 재원(과제번호: S2594138)과 산업통상자원부의 재원(과제번호: N0001395)으로 기술개발 지원사업의 지원을 받아 수행된 연구임.

\section{참고문헌}

김윤식. 한국산 새우난초속의 분류학적 연구. 식물분류학회지, 19: 273-287, 1989.

김동희, 안봉전, 김세기, 박태순, 박근혜, 손준호. 곰취(Ligularia fischeri), 미역취(Solidago virga-aurea), 삼나물 (Aruncus dioicus) 복합 추출물의 항염증 효과. 생명과학회지, 21: 678-683, 2011.

박예은, 권기석, 김병혁, 이중복. Lactobacillus rhamnosus BHN-LAB105를 이용한 발효 엉겅퀴의 항산화 및 미백효과

에 대한 유용성 평가. 아시안뷰티화장품학술지, 17: 1-13, 2019.

박장필, 이승인, 정종길. 천마의 근경과 지상부의 성분 및 항산화 활성 연구. 대한본초학회지, 30: 19-24, 2015. 박정용, 이지연, 이대영, 김형돈, 김금숙, 이승은, 서경혜. B16F10 세포에서 증숙도라지 추출물의 멜라닌 생성 억제 효과. 아시안뷰티화장품학술지, 17: 37-46, 2019.

배기화, 윤의수, 윤필용, 최용의. 새우난초(Calanthe discolor)의 조직배양으로부터 다신초형성을 통한 토양순화. 한국자

원식물학회지, 23: 7-13, 2010.

서진영. 피부노화의 특징과 발생기전. 대한피부연구학회지, 8: 187-194, 2001. 
서보영, 정은실, 김주영, 박해룡, 이승철, 박은주. 미더덕 아세톤 추출물이 산화적 DNA 손상억제 및 암세포 독성에 미치는 영향. Journal of Applied Biological Chemistry, 49: 227-232, 2006.

오승택, 정해수, 조문진, 송미영, 모상현, 서효현. 식물세포배양기술을 이용한 약용식물 개똥쑥 세포주 유도 및 세포주 추 출물의 wound healing effect. 한국산학기술학회논문지, 15: 5628-5636, 2014.

이나념, 최용의, 문홍구. 저온저장 음나무 배발생 캘러스로부터 체세포배 유도와 식물체 재생. Journal of Plant Biotechnology, 42: 388-395, 2015.

이경민, 정귀택, 박톤희. 목초액의 향균 및 $\mathrm{DPPH}$ 라디칼 소거 활성에 관한 연구. Korean Society for Biotechnology and Bioengineering Journal, 19: 381-384, 2004.

이영숙, 유민정. 계피 추출물의 항산화 효과 및 화장품소재의 응용. 아시안뷰티화장품학술지, 17: 69-80, 2019.

이종석, 곽병화. 韓國産 금새우난초(Calanthe striata R. Br)의 園藝的 品種에 關하여. Horticulture, Environment, and Biotechnology, 24: 62-67, 1983b.

이종석, 곽병화. 韓國産 금새우난초(Calanthe discolor Lindle)의 園藝的 品種에 關하여. Horticulture, Environment, and Biotechnology, 24: 144-148, 1983a.

조영제. Phellodendron amurense의 미백물질을 이용한 화장품 특성. Journal of Applied Biological Chemistry, 54: 108-113, 2011.

최정섭, 오정임, 황인택, 김성은, 전재철, 이병희, 김진석, 김태준, 조광연. 96-well plate를 이용한 DPPH free radical 소거활성 측정과 그 응용. 농약과학회지, 7: 92-99, 2003.

현명력, 최지용, 서정남, 소인섭. 제주 자생 새우란, 금새우란, 왕새우란의 분포와 외형적 특성에 관한 연구. 원예과학기술 지, 17: 497-499, 1999.

황재규, 윤종국, 한길환, 도은주, 이진상, 이은주, 김종부, 김미령. 한약재 복합 추출물이 항산화 및 항노화에 미치는 영향. 대한본초학회지, 26: 111-117, 2011. 


\section{中文摘要}

\section{虾脊兰茎愈伤组织的诱导、增殖及其抗氧化性能}

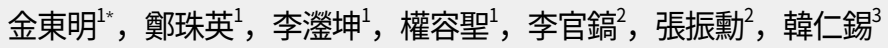

${ }^{1} \mathrm{KJM}$ 生物有眼公司生物工学研究所，首尔，韩国

2韩国产业技术大学生命化学工学科, 京畿道始兴市, 韩国

犹他大学工程学院化学工程系, 盐湖城, 美国

目的：建立从虾脊兰茎（Calanthe discolor Lindl's Flower Stalk, CFS）中诱导愈合组织的适宜条件和增殖条件 并分析其提取物的抗氧化性能以及皮肤刺激性水平。方法: 以NB0 ( $\alpha$-naphthaleneacetic acid (NAA) $0 \mathrm{mg} / \mathrm{L}$, benzyl adenine (BA) $0 \mathrm{mg} / \mathrm{L}$ ) , NB1 (NAA $0.2 \mathrm{mg} / \mathrm{L}$, BA $0.1 \mathrm{mg} / \mathrm{L}$ ) , NB5 (NAA $0.2 \mathrm{mg} / \mathrm{L}$, BA $0.5 \mathrm{mg} /$ L) 和NB10 (0.2 mg/L, BA $1.0 \mathrm{mg} / \mathrm{L})$ 为植物生长调节剂, 采用Murashige\&Skoog培养基诱导CFS愈伤组 织。通过超声波处理提取愈伤组织粉末, 并使用版伤组织提取物进行总酚含量、2,2-diphenyl-1-picrylhydrazyl (DPPH)自由基清除活性和人体皮肤刺激性试验。结果：用植物生长调节剂从CFS诱导愈伤组织中, NB5的愈伤 组织生长率最高, 为 $4.2 \pm 0.3 \mathrm{~g}$ 。愈伤组织提取物 NB0、NB1、NB5 和 NB10的总酚含量分别为 $33.71 \pm 0.27$ 、 $37.59 \pm 0.51 、 46.26 \pm 0.18$ 和55.92 $\pm 0.33 \mathrm{mg} \mathrm{GAE} / \mathrm{g}$ 。在不同浓度下，NB10的DPPH自由基清除活性均高于 NB0、NB1、NB5和NB10。与对照组 (10\%SLS) 相比, CFS愈伤组织提取物对人体皮肤的刺激性非常低。结 论: 诱导CFS愈伤组织的最佳的植物生长调节剂条件为NB10。CFS愈伤组织提取物具有显著的抗氧化活性和较低 的皮肤刺激性，可作为化妆品的功能材料。

关键词: 虾脊兰, 花梗, 愈伤组织, 抗氧化活性, 皮肤刺激性 
